\title{
The Dilemma of Health Access in Nigeria: Notes from Work in Progress
}

\author{
Ogoh Alubo* \\ Department of Sociology, University of Jos, Nigeria
}

Submission: January 18, 2018; Published: February 08, 2018

*Corresponding author: Ogoh Alubo, Department of Sociology, University of Jos, Nigeria, Email: ogohalubo@gmail.com

\section{Introduction}

Health is a much valued concept eulogized in Nigeria variously as being wealth, and a healthy nation is a wealthy nation. For the most part, health is reduced to medical services and the concern has revolved around policies to produce the necessary personnel and mobilize resources to "deliver" health care around the country. This delivery reveals that most of the population especially the poor and rural dwellers are underserved. The challenge has been exacerbated by insecurity especially in the Northeast where most facilities have been knocked out the Boko Haram rebellion; access remains a crucial challenge

In health discourse in Nigeria the primary concern is often about medical care and the related resources of hospitals and drugs and seldom about the conditions which make drugs and hospitals necessary. Through the medical conception, health care has become equated with medical care and health policies have stressed the intensification of curative services. There are hardly questions about the impact of this perspective on health problems. At issue is how medical care can solve problems whose root causes are political and economic. The common diseases in Nigeria, discounting epidemic outbreaks, are nutritional such as kwashiorkor and marasmus; parasitic like malaria and water borne such as cholera and guinea worm [1]. Other aspects of health such as preventive, promotive and rehabilitative dimensions are largely ignored. Politicians are comfortable with the medical perspective and the policy thrust has revolved around the following initiatives:

A. The training of more personnel to achieve a better practitioner-patient ratio. Nigeria's various governments have been proud of increases in both the ratio and absolute number of various cadres of personnel trained.

B. Building of more clinics, hospitals and treatment centres and expanding existing ones. Even in a situation where existing facilities are in crisis and most have atrophied, new ones are being built.
C. Procurement and better distribution of drugs, equipment and other materials.

This conception neatly fits the modernization path to health care development especially that it creates markets for drugs and equipment manufacturers. There is a lingering issue of access to available services. Initially, health was conceived as welfare and was provided by the state. Public health services run alongside the private and missionary facilities both of who charge fees. Thus in all public facilities, services, including food for hospitalized patients were free. Beginning from the mid1980s, new vocabulary of cost containment, cost sharing, Bamako Initiative were introduced. Through these, projects were woven around them; there were spirited attempts to make payment for services stick as part of health sector reform. AsIchoku \& Ifelunini [2] have argued, the changes are part of overall neoliberal policy propagated and imposed on subSahara Africa by the International Monetary Fund and the World Bank. The new objective became that of reducing government expenditure, irrespective of the impact on provision of health services.

The reforms (along with lower budgets, collapse in foreign exchange) have led to crippling shortages in public hospitals; routinely there are stock-outs of needed drugs and even reagents for the necessary tests. In a celebrated case in 2017, Nigeria's first lady, spoke out about the shortages of simple disposables like facemasks in Aso Villa (Presidential Palace) Clinic. It was a huge scandal because the clinic is where the first family or visiting Heads of State would first be attended to [3]. The shortages in public facilities account for the rise in medical tourism in Nigeria.

More widespread is the demands for monetary deposits before admission/commencement of treatment. When patients are unable to pay, treatment is denied and hospitalized patients are taken hostage, in the common language become "detained patients". Many spent weeks/months begging to offset bills and 
thereby gain their release. Others are able to get their case to the media where appeals are made to public spirited individuals. Nigeria now has a National Health Insurance Scheme which reaches less than four million, out of the estimated population of 160 million, mostly in the formal sector. The majority are compelled to pay for services out-of-pocket; a form of payment which accounts for $74 \%$ and may lead to financial catastrophe [4].

There are regular movements of Nigerians on medical tourism overseas. In 2017, President Mohammodu Buhari first took 50 days to the UK for some ear related infection and disappeared the second time for 103 days for an undisclosed condition. The rich and powerful, including the struggling middle class, regularly go abroad to avoid suffering any frustration of shortage of drugs, outmoded and poorly functioning equipment.

Those left out in the cold by health reforms are turning to medical outreach program organized by Non-governmental organizations, philanthropists provide services to chosen communities free. The choices are made by the financiers and because of the frustrations in the public sector and unaffordability of the private there are always huge crowds. Medical outreach as a remedy for access focuses mostly on primary health care and refer those who need tertiary care to the same services which was inaccessible ab inititio. Medical outreach is also being used as a mechanism to gain acceptance of military operations around Nigeria (http://www.sharpedgnews.com; http/www. vangaurdngr.com/2017/10/csm-naf-embarks-free-meningitisprevention-lecture-medical-outreach-enugu). To douse the general opposition to operation python dance in the South-East (in October 2017), the military began to provide free treatment to school children. The news spread quickly that the military was infecting the children with monkey box which broke out during the period. It took the intervention of the Federal Minister of Health to calm frayed nerves in the region [5].

The dilemma is precisely what to do with thousands who need medical care but cannot access this: is medical outreach which do not have any specific timetable either in dates or location the solution? In the interim, the government seems content that there is some functioning but unreliably public health system [6].

\section{References}

1. Alubo $O$ (2010) In Sickness and in Health: Issues in the Sociology of Health in Nigeria University of Jos Inaugural Lecture Series No 41, Nigeria.

2. AsIchoku H, Ifelunini A (2017) The unchanging undercurrents in health services delivery in Sun-Saharan Africa. International Journal of Health Services 47(3): 489-503.

3. Adetayo O (2017) Aisha Buhari decries state of Villa Clinic, demands probe, p. 16

4. Soyibo A (2009) National Health Accounts (NHA) of Nigeria Abuja: Federal Ministry of Health.

5. (2010) Federal Ministry of Health, National Strategic Health Development Plan 2010-2015 Abuja, Federal Ministry of Health.

6. Orude P (2017) Nigerian Army gives free medical outreach to Bauchi community ravaged by kidnappers. The Sun, $21^{\text {st }}$ April.

\section{Your next submission with Juniper Publishers} will reach you the below assets

- Quality Editorial service

- Swift Peer Review

- Reprints availability

- E-prints Service

- Manuscript Podcast for convenient understanding

- Global attainment for your research

- Manuscript accessibility in different formats

( Pdf, E-pub, Full Text, Audio)

- Unceasing customer service

Track the below URL for one-step submission

https://juniperpublishers.com/online-submission.php 